\title{
Agency and Famine in China's Sichuan Province, 1958-1962*
}

\author{
Chris Bramall ${ }^{\dagger}$
}

\begin{abstract}
A revisionist literature on the Great Chinese Famine has emerged in recent years. These revisionists focus primarily on the question of agency. They claim that that neither poor weather nor the excesses of local cadres can explain the extent of mortality; rather, responsibility lies squarely with Mao and the CCP leadership. Using county-level data on mortality, output, rainfall and temperature for Sichuan province, I argue that this revisionist view is unconvincing. Weather admittedly played only a minor role, and the zealotry of the Party centre contributed significantly to the death toll. However, variations in mortality between Sichuan's counties appear to have been essentially random - suggesting that differences in local cadre responses to central government policy were decisive in determining the scale of famine.
\end{abstract}

Keywords: Sichuan; mortality; Great Leap Forward; famine; weather; cadres

The history of the Great Chinese Famine of 1958-62 is being re-written. The conventional wisdom contends that famine caused about 30 million "excess" deaths across China and emphasizes the proximate causes of mortality: output decline, excessive procurements and over-consumption. ${ }^{1}$ However, this interpretation has been challenged in recent years on two counts. First, the revisionists (as I shall call them) claim the death toll was much higher. Second, they focus less on the question of proximate causes ("famine accounting") and more on the issue of agency. ${ }^{2}$ In particular, they criticize what they call the official Party explanation - that poor weather, withdrawn Soviet aid and local cadres caused famine - and argue instead that responsibility for the famine lies primarily with Mao Zedong himself.

* I am grateful to Kerstin Lehr and Julia Strauss for their comments on an earlier version of this article, to Tim Wright for alerting me to a number of sources, and to Kimberley Manning for allowing me an early look at the manuscript version of Kimberley E. Manning and Felix Wemheuer, Eating Bitterness: New Perspectives on China's Great Leap Forward and Famine (Vancouver: UBC Press, 2010).

$\dagger$ School of Oriental and African Studies, London. Email: cb81@soas.ac.uk

1 "Excess" meaning actual deaths minus the number of deaths that would have occurred if conditions had been normal. For conventional estimates of mortality, see Basil Ashton, Kenneth Hill, Alan Piazza and Robin Zeitz, "Famine in China, 1958-1961," Population and Development Review, Vol. 10, No. 4 (1984), and Judith Banister, China's Changing Population (Stanford, CA: Stanford University Press, 1987).

2 See especially Ralph Thaxton, Catastrophe and Contention in Rural China (Cambridge: Cambridge University Press, 2008), Thomas P. Bernstein, "Mao Zedong and the famine of 1959-1960," The China Quarterly, No. 186 (2006) pp. 421-45, and Kimberly Ems Manning and Felix Wemheuer (eds.), Eating Bitterness: New Perspectives on China's Great Leap Forward and Famine (Vancouver: University of British Columbia Press, 2011). 
In this article, I evaluate the revisionist view by considering the experience of Sichuan province. The first section reviews the conventional wisdom and the revisionist literature, and outlines my methodology. I then outline the scale and geography of mortality in Sichuan, and the extent of the food availability decline. The article then addresses the agency issues: what were the respective roles of bad weather, central government and local cadres in the Sichuan famine?

\section{Famine Perspectives, Old and New}

Much of the traditional literature has been pre-occupied with what is best described as famine accounting: measuring the respective roles played by output decline, distributional failure and increased food demand. This explanation of the famine goes as follows. First, the Great Leap Forward (1958-60) reduced grain production from its 1958 peak of 198 million tonnes to a trough of 137 million tonnes in 1961. The fall reflected reduced sown area, ill-advised changes in cropping patterns (dense planting, double rice-cropping and attempts to grow wheat on land previously used to store water during the winter), the diversion of labour from farming to steel production, and poor weather. Although China became a net grain importer, importing 4.5 million tonnes in 1961 compared with net exports of 2.7 million tonnes in 1958, grain availability still declined from 296 $\mathrm{kgs}$ to $215 \mathrm{kgs}$ per capita. ${ }^{3}$

However, and second, food availability decline (FAD) cannot explain the mortality rise in 1958, when grain output per capita was actually higher than in 1957. The 1958 crisis was precipitated instead by an unequal distribution of food supplies. ${ }^{4}$ Unequal distribution, caused by excessive state grain procurements and output over-reporting, also contributed to starvation during 1959-61, when food was abundant in some areas yet desperately scarce elsewhere. ${ }^{5}$ The third factor which contributed to the famine was a rise in per capita demand. This reflected "over-consumption" in the communal canteens (where food was freely available in 1958), and an increased demand caused by the frenzied mobilization of the population to work on irrigation expansion and steel

3 Guojia Tongjiju (State Statistical Bureau) (SSB), Xin Zhongguo 50 nian nongye tongji ziliao (Materials on 50 Years of Agriculture in New China) (Beijing: Zhongguo tongji chubanshe, 2000), p. 37; SSB, Zhongguo tongji nianjian 1983 (Chinese Statistical Yearbook) (Beijing: Guojia tongji chubanshe, 1984), pp. 422, 438. Chinese data for this period are unreliable, because of pressure to exaggerate output and the collapse of the statistical system; see Yue Wei, Dangdai Zhongguo de tongji shiye (China Today: Statistics) (Beijing, Zhongguo shehui kexue chubanshe, 1990). However, the sharp decline in output and rise in mortality is indisputable; we cannot be precise in analysing the famine, but we can still say much about its scale and its causes.

4 Thus supporting Sen's famous rejection of FAD as a general theory of famine. See Amartya Sen, "Food and freedom," World Development, Vol. 1, No. 6 (1989), pp. 769-81; Justin Yifu Lin and Dennis T. Yang, "Food availability, entitlements and the Chinese famine of 1959-61," Economic Journal, Vol. 110 (2000) pp. 136-58.

5 For procurements, see Thomas P. Bernstein, "Stalinism, famine and Chinese peasants," in Theory and Society, Vol. 13, No. 3 (1984), pp. 339-78; Robert F. Ash (ed.), Agricultural Development in China, 1949-1989 (Oxford: Oxford University Press, 1998); Kenneth R. Walker, Food Grain Procurement and Consumption in China (Cambridge: Cambridge University Press, 1984). 
production. ${ }^{6}$ These three causal factors together explain the scale of mortality during the Great Famine, although the precise contribution of each remains indeterminate. ${ }^{7}$

\section{The revisionist approach}

The new revisionist literature focuses on more fundamental issues than famine accounting. First, the revisionists aver that mortality was higher than the 30 million conventionally claimed. According to Cao, the famine claimed 32.5 million lives; Yang put the total at 36 million; Chang and Halliday computed 38 million deaths, and Dikötter claims over 45 million. ${ }^{8}$ Some of these estimates are not very plausible. ${ }^{9}$ However, a settled mortality toll will never be agreed. This is because of data problems (such as under-reporting of infant mortality, widely revealed in the 1982 retrospective fertility survey), and because there is no unambiguous way to calculate either "normal" deaths or the (hypothetical) number of "normal" births: without the famine, there would have been more births and therefore more infant deaths. ${ }^{10}$

The more significant contribution of the revisionists is to shift scholarly attention to the question of agency. The conventional wisdom did not ignore this question, and Mao-centred explanations of the famine are present in the older literature. ${ }^{11}$ However, most scholars - especially economists - have been

6 For communal dining, see Dali Yang, Calamity and Reform in China (Stanford, CA: Stanford University Press, 1996), and Gene H. Chang and G. James Wen, "Communal dining and the Chinese famine of 1958-61," Economic Development and Cultural Change, Vol. 46, No. 1 (1997) pp. 1-34. For increased food demand, see Chris Bramall, In Praise of Maoist Economic Planning (Oxford: Oxford University Press, 1993); Han Dongping, "Farmers, Mao, and discontent in China," at http://www.monthlyreview.org/091214dongping.php. The over-consumption argument is controversial because rationing replaced "free supply" in communal canteens before starvation appeared (Thaxton, Catastrophe and Contention in Rural China, pp. 124-25). There is also little econometric support: see James Kai-sing Kung and Justin Yifu Lin, "The causes of China's Great Leap famine," Economic Development and Cultural Change, Vol. 52, No. 1 (2003), pp. 51-73.

7 See for example Peter Nolan, "The causation and prevention of famines: a critique of A.K. Sen," Journal of Peasant Studies, Vol. 21, No. 1 (1993), pp. 1-28, and Sen's "Reply" in the same issue.

8 Cao Shuji, Da jihuang (The Great Famine) (Hong Kong: Time International, 2005), p. 282; Yang Jisheng, Mubei (Tombstone) (Hong Kong: Cosmos Books, 2008), p. 904; Jung Chang and Jon Halliday, Mao: The Unknown Story (London: Jonathan Cape, 2005); Frank Dikötter, Mao's Great Famine (London: Bloomsbury, 2010).

9 Dikötter's estimate is not new, as he admits (Dikötter, Great Famine, p. 333). Rather, it is simply a re-statement of the claim made by Chen Yizi and reported in Jasper Becker, Hungry Ghosts China's Secret Famine (London: Murray 1996), pp. 271-72. Chen's claim is suspect; he collected the data whilst a member of an investigative team appointed by Zhao Ziyang in the early 1980s which had the remit of discrediting the Maoist regime (and hence consolidating the political position of the reformers). And some of Dikötter's "new" provincial estimates have been in the public domain for many years: for Sichuan, for example, see Bramall, In Praise of Maoist Economic Planning, pp. 29697. More generally, Dikötter's claim that the Chinese archives provide more reliable data on mortality than published data is problematic. He asserts that archival reports can be trusted because "There was no political advantage to be had from declaring extra deaths" (Dikötter, Great Famine, p. 332) but this ignores how officials exaggerated deaths to evade or diminish state-imposed grain procurements.

10 For under-reporting, see Banister, Changing, pp. 233-35.

11 Bernstein ("Stalinism, famine and Chinese peasants") has long adhered to this view. 
pre-occupied with famine accounting, and done little to probe the underlying causes of the famine. The revisionists have been less reticent and their conclusions are striking. For one thing, they reject the official verdict of the Maoist era according to which the famine was seven-tenths natural and three-tenths manmade (qifen tianzai sanfen renhuo 七分天灾三分人祸). ${ }^{12}$ In particular, they argue that the 1958 famine cannot be explained by drought because there was no output decline, the only channel through which weather has an influence. And although revisionists agree that poor weather was a factor during 1959 61 , its impact was not severe enough to explain the scale of starvation. The main cause of famine was therefore entitlement failure, not weather-induced FAD.

However, the most striking revisionist claim is that the Party "centre" (central and provincial governments) was primarily responsible for the catastrophe. ${ }^{13}$ The famine, they argue, was no "tragedy of good intentions." Rather, it was engineered by a malevolent party-state and in particular by "China's ultra-leftist emperor, Mao Zedong, who was mainly responsible for relentlessly pushing leftism." 14 The radicalism of some provincial officials - such as Li Jingquan 李井泉 in Sichuan, Wu Zhipu 吴芝圃 in Henan and Zeng Xisheng 曾希圣 in Anhui also contributed to the scale of mortality. ${ }^{15}$ This coalition of Mao and radical provincial leaders precipitated the famine by imposing collective farming during 1955-56. This deprived farmers of their land-based entitlement to food, and enabled state-controlled rationing within communal canteens. Simultaneously, collective farms allowed the party-state to guarantee urban food entitlements by facilitating rural grain extraction. The Party centre was thus able to impose its will on both local cadres and farmers. According to Thaxton: "Da Fo's [the village he studied] political history ... re-affirms that Mao was the major causal agent of the Great Leap calamity - not the local party cadres who were blamed and scapegoated by Mao and allies at the center of the party." 16

12 The verdict was reversed after Mao's death; see Han Dongping, "Farmers, Mao, and discontent in China."

13 The revisionist approach to the Chinese famine has been influenced by Scott's description of how authoritarian states cause famine by pursuing a "high modernist" agenda designed to imposed order upon an "anarchic" countryside; see James C. Scott, Seeing Like a State (New Haven: Yale University Press, 1998). In the Chinese context, it can be contrasted with Shue's view that the "reach" of the central Maoist state was rather limited; see Vivienne Shue, The Reach of the State (Stanford, CA: Stanford University Press, 1988).

14 William A. Joseph, "A tragedy of good intentions: post-Mao views of the Great Leap Forward," Modern China, Vol. 12, No. 4 (1986), pp. 419-58; Thaxton, Catastrophe and Contention in Rural China, p. 325.

15 For the Henan famine, see Felix Wemheuer, "Dealing with responsibility for the Great Leap famine in the People's Republic of China," The China Quarterly, No. 201 (2010), pp. 176-94, and Becker, Hungry Ghosts. According to Chen, "Anhui's Zeng was a blatant political radical who almost single-handedly damaged Anhui" (Chen Yixin, "Under the same Maoist sky: accounting for death rate discrepancies in Anhui and Jiangxi," in Manning and Wemheuer, Eating Bitterness, p. 216). This was because Zeng played a key role in promoting massive irrigation projects in Anhui and, because they absorbed a large proportion of the farm workforce, these projects contributed significantly to the output decline.

16 Thaxton, Catastrophe and Contention in Rural China, p. 325. 
The revisionists acknowledge that the Party centre was no Leviathan. Where county and village leaders resisted procurement burdens by under-reporting output, by pre-emptive consumption (eating unripe crops) or by planting famine crops (such as potatoes), the mortality toll was lower. Local resistance was not always futile: it could and sometimes did vitiate central government policy. ${ }^{17}$ However, and this is a key revisionist point, such instances were rare. Almost invariably the will of central and provincial governments prevailed over the resistance of local cadres and farmers - who were nevertheless blamed in the early 1960s for the widespread starvation.

These revisionist claims are coherent and powerful. However, they raise methodological issues. For one thing, the claims derive from a small number of village surveys, which makes generalization difficult. ${ }^{18}$ For another, reliance on the memory of village informants is problematic. The passage of time inevitably adds colour to memories and, more importantly, memory is socially constructed: villagers are telling what they believe to be true, but their revelations are conditioned by a desire to preserve social "harmony" rather than to assign responsibility. ${ }^{19}$ Accordingly, we must subject the revisionist claims to careful scrutiny before accepting them. Such is the purpose of this article.

\section{Methodology}

In order to evaluate the revisionist claims, I start from the premise that bad weather should not be dismissed a priori. It is true that weather-based explanations were discounted even in the conventional wisdom. Kueh, whose work provides the most detailed assessment of the impact of poor weather, concluded that it explained barely 20 per cent of output decline in 1960 and 1961; the main culprit was a policydriven reduction in sown area. ${ }^{20}$ However, this analysis was based upon provincial weather data. This is methodologically very dangerous. It has, for example, been claimed that Sichuan experienced normal conditions during the famine years. Although this is accurate if one considers average provincial rainfall, the average is deeply misleading: in Sichuan's case, the combination of flooding in the west and drought in the east simply cancelled out to produce apparent normality. ${ }^{21}$ To avoid this problem we need a more disaggregated approach. I therefore utilize previously unused data on rainfall and temperature collected by county weather stations to assess the true impact of drought and flooding on mortality.

17 For examples cited by revisionists, see ibid. and Manning and Wemheuer, Eating Bitterness.

18 Provincial-level revisionist studies make little systematic use of the data and this limits their usefulness. See for instance Chen, "Same sky," in Manning and Wemheuer, Eating Bitterness.

19 Wemheuer ("Dealing with responsibility for the Great Leap famine," p. 178) is aware of this problem and claims that he is not assigning responsibility, but simply describing how memories of the famine vary across different social groups. Nevertheless, it is clear that he assigns most of the blame to the Party centre.

20 Y.Y. Kueh, Agricultural Instability in China (Oxford: Clarendon Press, 1995), pp. 207, 216, 224.

21 Daniel Houser, Barbara Sands and Erte Xiao, "Three parts natural, seven parts man-made," 2005, at http://repository.cmu.edu/sds/100/, p. 23. 
Second, the revisionist claim that local cadres were largely powerless to resist central and provincial government demands can be tested. If the claim is correct, there should be a pattern to the geography of mortality, reflecting the unequal but not random - treatment of localities in terms of procurement quotas. In particular, we would expect low mortality in localities where transport links were poor and growing conditions were unfavourable because these counties were not procurement targets: even the radicals did not expect big increases in output in mountainous areas with poor soil and water shortages, Conversely, we would expect to observe high mortality rates where transport links were good and agricultural productivity high because a powerful provincial and central government would have been able to impose high procurements on such counties, increasing death rates. However, if mortality rates were often driven by local cadre behaviour, we would expect a random pattern of mortality. Any counties dominated by "radical" cadres would have experienced very high mortality rates, while some prosperous and well-located counties would have emerged from the Leap with low numbers of famine deaths as "moderate" local cadres evaded and ignored the centre's policies.

Accordingly, we can evaluate the revisionist claims using county-level data on mortality, grain output and weather to identify whether the geography of mortality was random, or followed a pattern. ${ }^{22}$ A national analysis of county data would be ideal, but it is impracticable because of the volume of data required. In any case, spatial variations in famine mortality within Chinese provinces were typically so large that the province serves as an adequate test of the hypothesis that central government policy was decisive. Sichuan is an obvious choice here because it was the Chinese province with the highest absolute death toll. ${ }^{23}$ I therefore address these issues using county-level data drawn from the various County Records (Xianzhi 县志) and weather data collected at more than 20 Sichuan weather stations. I begin by outlining the scale and pattern of mortality.

\section{The Sichuan Famine, 1958-1962 24}

The famine in Sichuan started earlier (in 1958) than elsewhere: the all-China crude death rate (CDR) in 1958 was marginally higher than in 1957, but in Sichuan it rose from 12 to 25 per thousand. The Sichuan famine was also more severe than almost anywhere else in China. ${ }^{25}$ Not only was the average

22 I focus on output and mortality data for the counties because that is the lowest administrative level at which systematic analysis is possible.

23 By "Sichuan" I mean the province of the early 1960s, which comprised the cities of Chengdu, Chongqing and Zigong, and 15 special districts (zhuanqu, abbreviated as district throughout this article). For simplicity, "Chengdu district" includes Chengdu city and the counties of Wenjiang district, "Chongqing district" includes Chongqing city, the counties of Baxian, Qijiang and Changshou, and the counties of Jiangin district, and "Yibin district" includes Zigong.

24 Note that the death rate fell back to its 1957 level in 1962; for this reason, I focus on 1958-61.

25 For the literature on Sichuan, see Cao Shuji, The Great Famine, pp. 193-215 and Yang Jisheng, Tombstone, pp. 161-228; Cao Shuji, "1958-1962 nian Sichuan sheng renkou siwang yanjiu" ("Research on mortality in Sichuan province 1958-1962"), Zhongguo renkou kexue (Population 
CDR for 1958-61 (39 per thousand) well above the national average of 17 per thousand but also the peak rate in Sichuan (54 per thousand in 1960) was higher than in every Chinese province except Anhui (69 per thousand). ${ }^{26}$ Moreover, although the rate was higher in Anhui, the overall death toll was greater in Sichuan. ${ }^{27}$

\section{The proximate determinants of mortality 28}

The fall in per capita grain availability in the early 1960s played a key role in Sichuan's famine. The decline was sharp: rural availability fell from around 197 kgs per head in 1957 to a low of $133 \mathrm{kgs}$ in 1959 (Table 1). ${ }^{29}$ Some of this $64 \mathrm{~kg}$ decline reflected higher procurements. The net rate peaked at 38 per cent in 1959 , driven by "exports" to other provinces and in-kind debt repayments to the USSR. Extraction was facilitated by the completion of the railway between Baoji 宝鸡 in Shaanxi province and Chengdu, which linked Sichuan to the national network in September 1956. However, even if procurements had remained at their 1957 rate, rural grain availability in 1959 would still have been no higher than $155 \mathrm{kgs}$ per head. As subsistence required about $200 \mathrm{kgs}$ of processed grain, an allowance of only $155 \mathrm{kgs}$ would have meant starvation. ${ }^{30}$ We can therefore state unequivocally that the decline in per capita grain output - which contributed $42 \mathrm{kgs}$ of the $64 \mathrm{kgs}$ fall between 1957 and 1959 - was the main proximate cause of FAD. ${ }^{31}$

This calculation of the FAD, and the contribution of procurements to that decline, is crude. It exaggerates the decline in food supplies because it neglects

footnote continued

Science in China), No. 1 (2004) pp. 57-67); Bramall, In Praise of Maoist Economic Planning, pp. 281334; Stephen Endicott, Red Earth (London: I.B. Tauris, 1988), pp. 51-67. Ding Shu, "1960 nian qianhou Sichuan sheng de fei zhengchang siwang" ("Abnormal deaths in Sichuan before and after 1960"), 2009, at http://www.usc.cuhk.edu.hk/wk.asap; Wang Dongyu (Dong Fu), "Dayuejin shiqi Sichuan sheng dajihuang de teshu" ("Specific causes of the Great Famine in Sichuan"), 2009, at http://www. chinayj.net/StubArticle.asp?issue $=090106 \&=104$; Wang Dongyu, "Maimiao erqing cai huahuang Chuanxi dayuejin jishi" ("Ripening wheat seedlings and golden cauliflower - a record of the Great Leap Forward in western Sichuan"), 2000, at http:/www.yhcw.net/famine/. For the political background, see David S.G. Goodman, Centre and Province in the People's Republic of China (Cambridge: Cambridge University Press, 1986).

26 SSB, Quanguo gesheng zizhiqu zhixiashi lishi tongji ziliao huibian (Collection of Historical Statistical Materials on China's Provinces, Autonomous Regions and Centrally-Administered Cities) (Beijing: Zhongguo tongji chubanshe, 1990), pp. 2, 690 (LSTJ 1990).

279.4 million compared with 6.3 million according to Cao Shuji, The Great Famine, p. 282.

28 The mortality crisis began in Sichuan in 1958, even though there was no apparent decline in per capita grain output (see Bramall, In Praise of Maoist Economic Planning, pp. 309-13). However, because of space constraints, I concentrate here on 1959-61, when most deaths occurred.

29 Urban grain availability was higher but mortality nevertheless still rose significantly.

30 This includes an allowance for animal feed and seed, and assumes the consumption of additional calories from meat, vegetables and fruit (see Ash, Agricultural Development, p. 141)

31 Of the 103 counties for which I have data for 1957 and for 1959-61, only eight (all located in mountainous western Sichuan) reported a rise in average per capita output whereas 95 reported a decline. For the sample, the average decline in per capita output was $28 \%$, similar to the figure for the entire province $(32 \%)$. 
Table 1: Grain Output, Procurements and Mortality in Sichuan

\begin{tabular}{ccccccr}
\hline $\begin{array}{c}\text { Net grain procurement } \\
\text { rate (\%) }\end{array}$ & $\begin{array}{c}\text { Grain output } \\
\text { (m tonnes) }\end{array}$ & $\begin{array}{c}\text { Grain } \\
\text { availability per } \\
\text { head (kgs) }\end{array}$ & $\begin{array}{c}\text { Crude death } \\
\text { rate(per 1,000) }\end{array}$ \\
1955 & 23 & & Rural & Urban & Rural & Urban \\
1956 & 23 & 15.70 & 194 & 371 & 9 & 10 \\
1957 & 26 & 17.23 & 209 & 296 & 11 & 9 \\
1958 & 26 & 17.07 & 197 & 238 & 12 & 11 \\
1959 & 36 & 17.89 & 209 & 406 & 26 & 15 \\
1960 & 27 & 12.66 & 133 & 350 & 49 & 21 \\
1961 & 20 & 10.70 & 135 & 197 & 54 & 24 \\
1962 & 19 & 9.55 & 134 & 217 & 30 & 23 \\
& 26 & 11.49 & 160 & 358 & 15 & 14
\end{tabular}

Notes:

"Availability" means grain which could be used directly and indirectly (feed, food processing etc.). It is net of husking, resales, and exports to the USSR and other provinces but excludes stock changes.

Sources:

Zhonggong Sichuan sheng wei yanjiushi (Research Unit of the Sichuan Committee of the (CP), Sichuan sheng qing(Conditions in Sichuan) (Chengdu: Sichuan renmin chubanshe, 1984) pp. 559, 571; Sichuan tongjiju (Sichuan Statistical Bureau), Sichuan tongji nianjian 1990 (Sichuan Statistical Yearbook 1990) (Beijing: Zhongguo tongji chubanshe, 1990) (SCTJNJ 1990), pp. 57-58.

stock depletion and higher husking rates during the famine years. ${ }^{32}$ Moreover, it underestimates the impact of procurements by ignoring the indirect effects on output: villagers could often meet quotas only by selling seed grain, thus compromising the harvest in the following year. Yet despite this imprecision, it is certain that Sichuan experienced FAD and that this decline made a significant contribution to the famine. This suggests that Sichuan's experience differed from Thaxton's Da Fo village (Henan), where there was seemingly no decline in per capita output.

\section{Spatial variations in mortality}

Although most Sichuan counties experienced higher mortality during 1959-61, there were massive variations in crude death rates (Figure 1). ${ }^{33}$ Mortality rates were low in three places. The first was in Sichuan's cities. The urban CDR averaged a (comparatively) modest 21 per thousand during 1958-61: in both Chengdu and Chongqing districts, the mortality rate in the urban core was well below that in the outlying counties. ${ }^{34}$ Second, mortality was low in

32 Villagers across Sichuan responded to famine by consuming brown rather than white rice, and by replacing wheat and rice with calorie-dense tubers. A kilogramme of unhusked grain thus translated into more calories in 1961 than in 1956-57.

33 I have used data on CDRs for 123 Sichuan counties to construct Figure 1, and the district median as a proxy where data are missing. CDRs provide an imprecise measure of the demographic impact of famine, but population growth rates between 1957 and 1964, and survival rates by age and county at the time of the 1982 Census, confirm the spatial patterns shown.

34 Sichuan tongjiju (Sichuan Statistical Bureau), Sichuan tongji nianjian 1990 (Sichuan Statistical Yearbook 1990) (Beijing: Zhongguo tongji chubanshe, 1990) (SCTJNJ 1990), p. 58; Chongqing tongjiju 
Figure 1: Crude Death Rates by County in Sichuan, 1958-1961 (annual average, per 1,000)

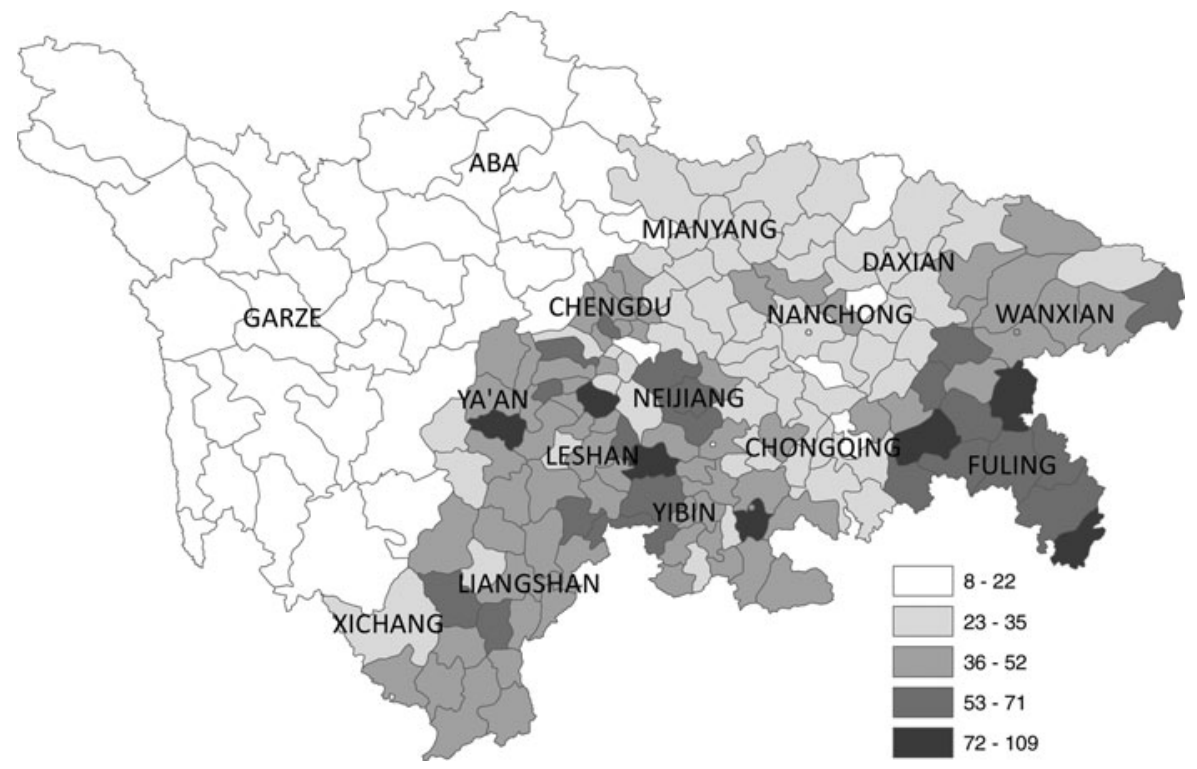

Notes:

The (named) districts, and the county boundaries, are those of 1964. The famine death rate in the median Sichuan county was 36 per thousand.

Sources:

Various Local Records (full details are available from the author); Neijiang diqu renkou zhi (Population Records of Neijiang District) (Beijing: Zhongguo renmin chubanshe, 1993); Yang Jisheng, Mubei (Tombstone) (Hong Kong: Cosmos Books, 2008), pp. 532-33. Where the sources conflict, I have used the higher rate.

Himalayan Aba 阿坝 and Ganzi 甘孜 districts, suggesting that Sichuan's Tibetan minority suffered less than the Han majority; official estimates of the CDR for the Tibetan minority show that it peaked at 18 per thousand in 1961, well below the provincial peak of 54 per thousand in $1960 .{ }^{35}$ Third, mortality was generally lower in northern Sichuan and the central Sichuan basin.

By contrast, the highest district level of mortality was recorded in Fuling 涪陵, where the CDR for 1958-61 averaged 64 per thousand. Even this understates the intensity of the famine. The death rate actually exceeded 100 in six of the eleven counties in one year or other in Fuling. Death rates were also high in Ya'an 雅安 and Neijiang 内江 districts (47 and 48 per thousand in the respective median

footnote continued

(Chongqing Statistical Bureau) Chongqing jianshe sishinian (40 Years of Building Chongqing) (Beijing: Zhongguo tongji chubanshe, 1989); Chengdu tongjiju (Chengdu Statistical Bureau), Chengdu tongji nianjian (Chengdu Statistical Yearbook 1999), at http://www.chdstats.gov.cn/.

35 Sichuan sheng renkou pucha bangongshi (Sichuan Population Census Office), Sichuan Zangzu renkou (The Tibetan Population of Sichuan) (Beijing: Zhongguo tongji chubanshe, 1994), p. 172. 
counties). Moreover, starvation was commonplace even close to the provincial capital: the CDR in the median county of Chengdu district was 45 per thousand for 1958-61. But even these horrendous district-level medians only hint at the exceptionally high CDRs recorded in some Sichuan counties. It exceeded 100 per thousand in 23 counties in one or other year, and surpassed 150 per thousand in five. ${ }^{36}$ In the three counties of Dayi 大邑, Xiushan 秀山 and Yingjing 水经, the rate exceeded 100 in successive years. Unsurprisingly, it was a Fuling county (Shizhu 石柱) which recorded the highest three-year CDR (109 per thousand) reported in Sichuan for 1959-61. ${ }^{37}$

One of the key tasks, then, in assessing the Sichuan famine is to explain these spatial variations in mortality. It is of course important to explain why the average provincial crude death rate rose from 12 per thousand in 1957 to 54 per thousand in 1960. However, we also need a theory which explains the massive local variation in death rates. Why was it that the CDR in Pi 龵 county soared from 12 per thousand in 1956 to 175 per thousand in 1960, whereas in nearby Shuangliu 双流, which started from the same mortality rate in 1956, it never exceeded 37 per thousand?

\section{Bad Weather and the Sichuan Famine}

In order to explain both the overall mortality rise and the spatial variations in mortality across Sichuan, I start by assessing the impact of poor weather. Was mortality extreme in (for example) Pi county because it was the victim of poor weather?

Although weather has sometimes been dismissed as a propaganda-based explanation of the Great Famine, there is nothing inherently implausible in the notion that bad weather played a key role in the Sichuan catastrophe. Chinese geographers estimate that there is 70 per cent chance of drought - the main threat every ten years in the area around Fuling and Mianyang 绵阳, and about 30 per cent elsewhere in the Sichuan basin. ${ }^{38}$ Moreover, there is some evidence, admittedly not entirely consistent, that drought caused famine in $1937 .{ }^{39} \mathrm{~A}$ weather-based explanation of the Sichuan famine therefore cannot be ruled out a priori.

36 In the counties of Pixian (175 per 1,000 in 1960), Shizhu (168 in 1960), Rongxian (165 in 1960), Fengdu (163 in 1960) and Yingjing (151 in 1959); see Yang Jisheng, Tombstone, p. 533 for Rongxian and Shizhu. Other rates from Xianzhi (County Records) (XZ): Pi XZ (Chengdu: Sichuan renmin chubanshe, 1989), p. 131; Yingjing $X Z$ (Chongqing: Xinan shifan daxue chubanshe, 1998), pp. 111-13; Fengdu XZ (Chengdu: Sichuan kexue jishu chubanshe, 1991), pp. 94-95.

37 Yang Jisheng, Tombstone, p. 533.

38 Zhongguo kexueyuan Chengdu dili yanjiusuo (Chengdu Geographical Research Institute, Chinese Academy of Science), Sichuan nongye dili (An Agricultural Geography of Sichuan) (Chengdu: Sichuan renmin chubanshe, 1980).

39 Bramall, In Praise of Maoist Economic Planning, pp. 282-91. The infant mortality rate in 1937 was seemingly higher than in 1959 in Shifang county on the Chengdu plain; see William R. Lavely, "The rural Chinese fertility transition," Population Studies, Vol. 38, No. 3 (1984) pp. 365-84. 
Accordingly, I proceed to assess the effects of bad weather by employing the figures assembled in two datasets covering respectively 160 and 205 weather stations across China. By using the data collected at a weather station in each Sichuan district, we can establish the pattern of rainfall. ${ }^{40}$ As far as $1958-61$ is concerned, it is true that rainfall at the median Sichuan weather station was just 4 per cent higher than the 1951-80 average, a modest variation. However, this provincial median is misleading. First, rainfall is only one dimension of weather; we must supplement it with temperature data. Second, the provincial median averages out extremes of flooding and drought: flooding in Mianyang and Chengdu districts - rainfall there was over 30 per cent above average for the four years - cancelled out drought in (for example) Chongqing, where rainfall was 20 per cent below average. Third, the four-year median obscures sharp year-on-year fluctuations, and acute summer drought. In Neijiang, for example, rainfall was 39 per cent below normal in 1958. In Fuling, the shortfall was 367 mms over the whole of 1959 and rainfall was barely 44 per cent of average in July-August. In 1960, the Fuling rainfall deficit was less than in 1959 and 1961. However, this disguises the 47-day drought between 17 July and 1 September (the worst of the Maoist era): only $34 \mathrm{mms}$ of rain fell, as against $245 \mathrm{mms}$ in a normal year.

To capture the impact on output of these regional, annual and seasonal variations, I estimate a production function incorporating an aridity index. I assume that the grain production function was Cobb-Douglas in form, and that the main determinants of output were grain sown area, the size of the rural labour force, the input of fertilizer, a time trend and the degree of aridity. When the weather is normal, the aridity index takes a value of one and its natural log is zero. In order to calculate the aridity index, I use monthly data on rainfall and temperature for five Sichuan weather stations during May-August, the main growing period for rice. ${ }^{41}$ The provincial average is based on the sum of the deviations at the five stations. I also assume that only drought conditions seriously affect output because of the dominance of rice production across Sichuan; only if rice had been submerged for a long period would output losses have been significant, and this was a rare event in well-drained paddy fields. ${ }^{42}$

My calculations suggest that poor weather played a modest role in causing the Sichuan famine. The coefficient on the aridity index obtained from the

40 Rainfall and temperature data come from the 205 and 160 station national sets at http://dss.ucar.edu/ datasets/ds578.5/data/ and http://dss.ucar.edu/datasets/ds578.1/data/ respectively. Some of Sichuan's County Records (e.g. Shehong, Pixian and Anyue) also report rainfall and temperature data.

41 These five stations (Pengshui, Nanchong, Chengdu, Yibin and Bazhong) together cover the key grainproducing parts of the province. I ignore western Sichuan, where grain production and population density were low. For aridity indices, see Bernard Oury, "Allowing for weather in crop production model building," Journal of Farm Economics, Vol. 47, No. 2 (1965), pp. 270-83. Here I use the de Martonne index, but the conclusions are insensitive to the index used.

42 The late 1950s and early 1960s were extraordinarily wet across the western Sichuan basin (including Chengdu). However, the County Records make little mention of damage caused by flooding; drought was evidently the main problem. 
production function is 0.33 . This suggests that drought reduced grain output (relative to 1957) by about 5 per cent in 1959, 4 per cent in 1960 and 4 per cent in 1961. Drought thus explains about 20 per cent of the output decline in 1959, 11 per cent in 1960 and nine per cent in 1961. These are modest contributions and, given that poor weather can only cause famine via output decline and that output decline was only one cause of famine, ${ }^{43}$ it follows that poor weather cannot have been the main causal factor. More precisely, $42 \mathrm{kgs}$ of the $66 \mathrm{~kg}$ decline in food availability in 1959 (compared with 1957) can be explained in terms of output decline, and only 20 per cent of that $42 \mathrm{~kg}$ output decline can be explained by the weather. In other words, only $8 \mathrm{kgs}$ (12 per cent) of the Sichuan FAD in 1959 - when drought was most intense - can be explained by poor weather.

These econometric procedures are crude. There are potential problems associated with colinearity and endogeneity, ${ }^{44}$ the data are not fully reliable, and we really need separate production functions for each Sichuan agricultural region because of differences in the composition of grain output. Additionally, it would be better to calculate an aridity index using data for every Sichuan weather stations (not just five) and for every month (and not merely the summer). Nevertheless, the approach appears relatively robust. Experimentation with different forms of the production function does not significantly alter the conclusions. Moreover, district-level evidence suggests little correlation between weather fluctuations and output. For example, output in the districts of Yibin 宜宾, Neijiang and Daxian 达县 was over 40 per cent lower in 1961 than in 1957, yet rainfall was virtually normal. Chongqing and Neijiang (as previously noted) were hard-hit by drought in 1958, yet per capita output actually rose.

Still, we cannot ignore the contribution of weather in parts of Sichuan. In Fuling district, for example, in the summer of 1961, rainfall was barely 10 per cent of normal and the fall in rice production - the crop most affected by summer drought - was particularly severe. Across Sichuan, rice output in 1961 was 50 per cent below its 1958 level, but in Dianjiang 垫江 and Fuling counties, production was barely 20 per cent of the 1958 peak. ${ }^{45}$ But drought was most damaging in Fuling in 1959, when rainfall was 50 per cent of the total required. The production function approach discussed earlier suggests that this 1959 drought reduced grain output by 14 per cent compared with 1957 . As the total fall in output in 1959 was 24 per cent, poor weather was evidently the most important factor in reducing output in that year.

43 The 1958 mortality crisis was not due to output decline, and both high procurements and increased food demand contributed significantly to mortality during 1959-61.

44 For example, I proxy the supply of fertilizer using the pig stock (chemical fertilizer use was negligible in the late 1950s). The pig stock was certainly a determinant of grain output (more pigs meant more fertilizer). However, causality also ran in reverse: increased grain output meant more pig feed. 


\section{Agents of Famine: The Provincial Government and Local Cadres}

Fuling's experience, however, was the exception. For Sichuan taken as a whole, human agency, rather than poor weather, was the key causal factor. What, however, of the respective parts played by the provincial government and local cadres in the Sichuan catastrophe? Should the Party centre be blamed, as the revisionists assert, or does much of the responsibility lie with local cadres?

\section{The role of the provincial government}

The "radicalism" of Li Jingquan, the provincial Party secretary, undoubtedly played a deadly role. ${ }^{46}$ Of course the policies pursued in Sichuan originated with the central government, but Li's radical interpretation of them undeniably exacerbated the famine.

$\mathrm{Li}$ was a radical well before the Leap. Although the pace of collectivization seemed slow in the mid-1950s, this was because Li had promoted the creation of large lower stage co-operatives in 1955. These proved very inefficient, so much so that they had to be dissolved before higher stage co-operatives (that is, collectives) could be established. Li also pushed for high rates of investment, accepted high procurement quotas and was an ardent advocate of the 12 Year Agricultural Plan in the mid-1950s, which together created the "supply crisis" of 1956-57, an eerie foretaste of the Leap. ${ }^{47}$

Li Jingquan's radicalism was not extinguished by the failures of the mid-1950s. Instead, Sichuan was one of China's most radical provinces during the Leap. For example, Li was keen for Sichuan to increase its net grain exports (to the USSR and other provinces). In consequence, and despite being a modest per capita grain producer, Sichuan exported more grain than any other province in every year between 1957 and 1961, and was a net exporter even at the height of famine in 1959-60.48 At a local level, the burden was often crippling. For example, Shifang 什邡 county on the Chengdu plain exported a staggering 44 million kgs of its grain output of 95 million kgs in 1959.49

A second instance of Li's radicalism was the high investment rate, especially in 1959 when it reached 35 per cent. Although this was lower than the national average (44 per cent), the burden in terms of "lost" consumption was much higher in a poor province like Sichuan. ${ }^{50}$ Third, Li Jingquan promoted rapid rural industrialization. This drew much labour out of farming and into the cities, such that Sichuan's rural labour force fell by 17 per cent during 1957-58, whereas it rose by

$46 \mathrm{Li}$ escaped much of the official blame for the Sichuan catastrophe but many scholars are less charitable; see Ding Shu, "Abnormal deaths in Sichuan," and Wang Dongyu, "Specific causes of the Great Famine in Sichuan."

47 Goodman, Centre and Province in the People's Republic of China, pp. 50-51.

48 Ash, Agricultural Development, p. 130.

49 Shifang XZ (Chengdu: Sichuan renmin chubanshe, 1988), pp. 10-20, 18-55. Of this, 30 million kgs went to the USSR.

50 Bramall, In Praise of Maoist Economic Planning, pp. 322-24. 
4 per cent nationally. ${ }^{51}$ With many farmers temporarily engaged far from home in iron and steel production - for example, 30,000 of the farmers resident in Renshou 仁寿 county had been sent to Hongya 洪雅, some $80 \mathrm{kms}$ to the west - the residual farm labour force was not large enough to collect the harvest. ${ }^{52}$ For Sichuan as a whole, 10 per cent of the (notional) 1958 harvest allegedly rotted in the fields. ${ }^{53}$ Fourth, Sichuan created communes unusually quickly. By the end of September 1958, 97 per cent of households were in communes. ${ }^{54}$ By contrast, Guizhou accomplished this only in February 1959. Canteens were also introduced earlier (by October 1958, 95 per cent of households were eating there), ${ }^{55}$ closed late, and provided a larger proportion of "free" food than elsewhere. ${ }^{56}$ Additionally, Sichuan introduced brigade-level accounting, despite the prevalence of team-level accounting in other provinces and Mao's own opposition. ${ }^{57}$ Finally, Sichuan pioneered changes in cropping patterns. The province moved quickly to eliminate winter-flooded fields (dongshuitian 冬水田) ${ }^{58}$ whereby paddy fields were flooded during the winter as a hedge against drought the following spring - so that winter wheat acreage could be expanded. ${ }^{59}$ Simultaneously, sown area was cut: Sichuan's grain-sown area fell by 15 per cent in 1959 compared with the national fall of only 9 per cent. ${ }^{60}$ These cuts in sown area, along with falling yields, were central to declining grain output in 1959-61.

\section{Spatial variation and the role of local cadres}

Nevertheless, neither the influence of central government nor the radicalism of $\mathrm{Li}$ Jingquan explains the marked spatial variation in mortality rates. Consider the experience of Chengdu district. In such a topographically similar area, weather variations between counties were comparatively small. Moreover, Chengdu's counties were similar in economic geography, economic structure and per capita

51 LSTJ 1990, pp. 3, 691

52 The scale and impact of migration during the famine has been little explored. However, it appears that the controls on migration imposed by the Party Centre helped to intensify the scale of mortality. By preventing able-bodied workers from returning to their home villages, the harvest was lower than it would otherwise have been, especially in 1958. Moreover, the rationing of food supplies via communal canteens made it hard for "outsiders" to migrate to communes with higher per capita food supplies: such outsiders had no entitlement to food and therefore migration offered little panacea.

53 Yang Chao, Dangdai Zhongguo de Sichuan (Contemporary China: Sichuan) (Beijing: Zhongguo shehui kexue chubanshe, 1990), p. 93fn.

54 Ibid. p. 91.

55 Ibid. p. 91

56 Goodman, Centre and Province in the People's Republic of China, pp. 150, 151, 236.

57 Ibid., pp. 138, 144, 154, 158.

58 Dongshuitian were prevalent in Sichuan; e.g. they comprised $70 \%$ of paddy fields across Fuling district in the mid-1950s; see Ye.A. Afanas'yeskiy, Szechwan (New York: JPRS Translation No. 15308, 1962), p. 301.

59 The abolition of dongshuitian contributed greatly to famine because, until the irrigation schemes begun in the 1950s were completed, farmers had no recourse to alternative water supplies in the event of severe droughts.

60 SSB, Materials on 50 Years of Agriculture, p. 34; SCTJNJ 1990, p. 130. 
output: located on the fertile Chengdu plain and within close reach of the new Chengdu-Baoji railway, these were Sichuan's most prosperous counties. Unsurprisingly, they were singled out for grain procurements and industrial development by the Party centre. Yet despite their structural and locational similarities, the variation in mortality rates amongst these counties in 1960 is striking (Figure 2).

The evidence suggests that differences in local cadre responses to central and provincial government initiatives explain these mortality variations. Where cadres meekly accepted high procurement quotas, cuts in sown area and orders to invest heavily in industry, mortality soared. ${ }^{61}$ It was no accident that the death rate (175 per thousand in 1960) was especially high in Chengdu's Pi county. The compliers of the County Records blame local radicalism for this, and no wonder. Its cadres were radicalized by Mao's visit on 16 March 1958 and by the presence of Deng Xiaoping - a radical in those days - on 18 March. Consequently, the county established Sichuan's first commune on 19 August 1958. Moreover, Pi's cadres also accepted high procurements, which rose from 48 million $\mathrm{kgs}$ of unhusked grain in 1956 to 135 million in 1959 , over 50 per cent of output. ${ }^{62}$

Yet the mere fact of a visit by Mao does not explain the intensity of famine: it was the response of local cadres that was critical. Neighbouring Guan 灌 county, now Du river dam (Dujiangyan 都江堰) city, was also visited by Mao, this time on 21 March 1958. The policies adopted in the county adhered closely to the Party centre line. Local cadres increased grain procurements from 37 million $\mathrm{kgs}$ in 1957 to 50 million in 1959, and doubled the non-agricultural population between 1957 and 1959 to develop industry and widen the area irrigated by the celebrated Dujiangyan. Even so, Guan's cadres were far less zealous than their neighbours in Pi county. Even at its peak in 1960, Guan's crude death rate of 50 per thousand was less than the provincial average and far below the 175 per thousand in Pi county. ${ }^{63}$ It was a similar story in Shuangliu (where peak mortality rate was only 37 per thousand) and in Chongqing county ( 27 per thousand).

It seems, then, that local cadre responses, not differential economic treatment by the Party centre, best explain mortality variations around Chengdu. The evidence for other parts of Sichuan supports this contention. As shown above, Fuling district was hard-hit by drought, and mortality rates were well above the provincial norm. Yet drought cannot explain why modest 1960 mortality rates in $\mathrm{Ba}$ 巴, Changshou 长寿 and Pengshui 彭水 counties of 31, 41 and 55 per thousand respectively co-existed alongside the very high rates of 168 and

61 Although we lack proper evidence, the response of local cadres towards the policies of the Party centre in respect of migration was also crucial. In counties where local cadres limited the exodus of able-bodied workers to work on industrial projects outside the county boundaries, the 1958 harvest would have been higher. Conversely, cadres willing to accept large numbers of in-migrants ran the risk of pushing up mortality by exhausting local food supplies. In other words, the Party centre was responsible for imposing the institutions of collective farming and communal dining, but the interpretation and implementation of these policies by local cadres was critical in determining local mortality rates.

62 Pi XZ, pp. 19, 131, 253-54, 490, 492.

63 Guan XZ (Chengdu: Sichuan renmin chubanshe, 1991), pp. 121-22, 130, 460. 
Figure 2: Crude Death Rates on the Chengdu Plain by County, 1960 (deaths per $1,000)$

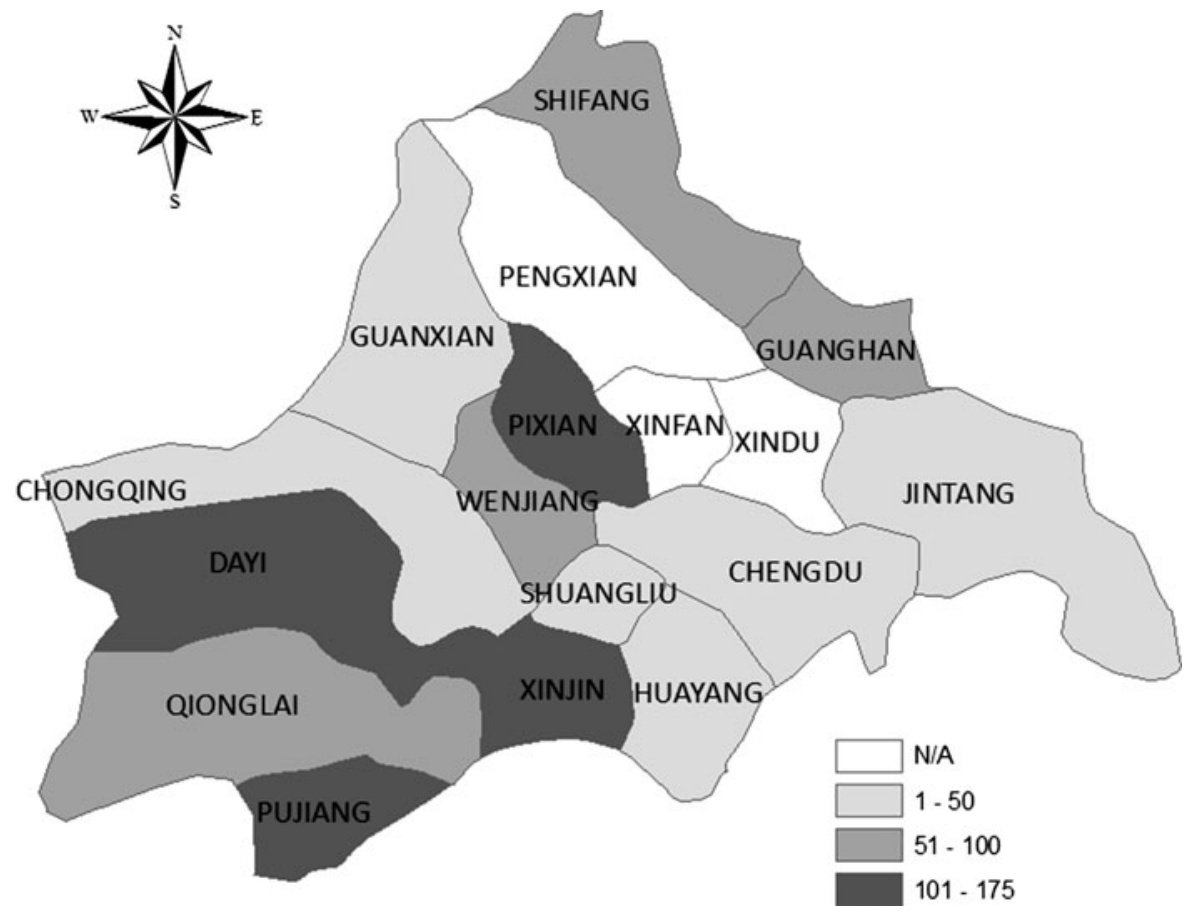

Notes:

I use the Sichuan urban average (see SCTJNJ 1990, p. 58) for Chengdu city. There are no data for Pengxian, Xinfan and Xindu. Sources:

As for Figure 1.

163 per thousand suffered by neighbouring Shizhu and Fengdu 丰都 respectively. ${ }^{64}$ The whole region suffered drought, not just one or two counties. Consider also Ya'an district, west of Chengdu. The peak death rate in the median Ya'an county was 67 per thousand, but this again disguises local variations. In Shimian 石绵, the death rate was below 33 - yet in nearby Yingjing, it reached 151 per thousand in 1959 and 112 per thousand in $1960 .{ }^{65}$ Ya'an district was a procurement target: most of its counties were accessible by road from Chengdu. However, it was the radicalism of Yingjing's two Party secretaries that caused starvation. 1958 saw both the early creation of communal canteens (the process was completed by September) and a massive campaign to promote steel production. ${ }^{66}$ The resultant labour shortages ensured that much of the

64 Fuling $X Z$ (Chengdu: Sichuan renmin chubanshe, 1995), p. 233; Dianjiang XZ (Chengdu: Sichuan renmin chubanshe, 1993), p. 131; Ba XZ (Chongqing: Chongqing chubanshe, 1994), p. 656; Changshou XZ (Chengdu: Sichuan renmin chubanshe, 1997), p. 178.

65 Yingjing $X Z$, p. 112.

$66 \mathrm{Yu}$ Xiguang at http://www.yhcw.net/famine/reports/10018.htm. 
harvest was not collected. Worst followed in 1959 when grain procurement rose from 4 to 10 millions kgs; with 1959 output down by about 50 per cent because of labour shortages, this meant that the (gross) procurement burden rose from 14 to a colossal 80 per cent. In 1960, gross procurements increased still further, reaching 11 million $\mathrm{kgs}$ - more than the grain harvest for that year ( 9 million tonnes) making widespread starvation almost inevitable. ${ }^{67}$

This contention that variations in mortality patterns across Sichuan were largely random is supported by the evidence in Figure 1. There is little to suggest that mortality was concentrated along the main transport arteries (the BaojiChengdu railway and the central riverine zone), though that is what one would expect if central government procurement policy was decisive. Moreover, prosperity offered no security against starvation: Pixian's population starved, yet Chongqing's was barely affected even though both were amongst Sichuan's most prosperous counties. But poverty offered no inoculation against famine either: Fuling's Shizhu and Fengdu counties were amongst the poorest in the entire Sichuan basin and yet mortality was extreme in both. ${ }^{68}$

This conclusion that mortality patterns lack any obvious pattern is supported by formal econometrics. To test the conclusion, I assume that changes in mortality between 1956-57 and 1958-61 were a function of three factors: the extent of the output decline, the level of per capita output in 1956-57, and location. If mortality was driven by central government policy, we would expect the highest mortality rates in counties which were procurement targets - that is, counties which produced a surplus (as measured by per capita output), and which were accessible (so that the surplus could be extracted and exported to other cities and provinces). In other words, the revisionist hypothesis implies that the regression coefficient on both per capita output in 1956-57 and location should be positive. ${ }^{69}$ As it turns out, both location and per capita output in 1956-57 are statistically significant in the sample of 84 Sichuan counties for which I have data. However, the results are not robust. Rather, they depend upon the inclusion of five poor counties located on the Himalayan plateau, which produced little grain (because of geographical disadvantage) and which did not even establish communes until the 1970 s. $^{70}$ Once these five anomalous counties are excluded

67 Yingjing $X Z$, pp. 281, 453. Rao Qing, Party secretary in 1960, was later sentenced to eight years in a labour camp for his failures.

68 Ó Gráda is right that the famine generally hit hardest in provinces which were poor, such as Sichuan, Anhui and Henan; see Cormac ó Gráda, Famine (Princeton, NJ: Princeton University Press, 2009), pp. 252-54. However, my results show little correlation between output per head and mortality at a subprovincial level in Sichuan.

69 In this set-up, I use average output for 1956-57 to smooth output anomalies in 1957. I employ adjusted grain output data because reported output provides a misleading impression of food supplies by taking no account of differences in output composition or husking rates; raw grain data thus exaggerate the level of per capita output in (say) the rice-producing counties of the Chengdu plain relative to the corn and potato-producing counties of the central Sichuan basin. Peripheral counties are those located outside the central riverine zone and away from the provincial railway network.

70 Land reform was not attempted here until the late 1950 s because these counties were so poor, and because of separatist sentiment amongst China's Tibetan population in the early and mid-1950s. 
from the sample, neither the coefficient on per capita output nor that on location is statistically significant.

In short, the geography of mortality across Sichuan was determined primarily by the attitude of local cadres and (to a lesser extent) the weather. Mortality rates in counties like Pi, Yingjing and Shizhu were exceptionally high because their cadres were over-zealous in their interpretation of the policies pursued during the Leap - not because they were targeted by central or provincial government.

\section{Conclusion}

The Sichuan evidence does not support the revisionist contention that the scale of the famine was caused primarily by the Party centre. Although the famine was man-made, revisionist emphasis on the role played by central and provincial governments seems over-stated. Differences in the attitudes of provincial leaders certainly help to explain variations in mortality across provinces. ${ }^{71}$ But local leaders were as culpable as the "malevolent" provincial and central committee cadres who constituted the Party centre. As I have argued, the geography of mortality was essentially random across Sichuan: it is hard to detect the guiding hand of a radical provincial leader in any of this. Mortality rates were not systematically higher in those counties which might have been singled out - by their productivity and transport links - by a radical provincial leader for penal procurement quotas. On the contrary. The variation in mortality between counties with very similar economic structures and located within the same district is so great as to defy systematic explanation. It can be plausibly explained only by differences in local cadre behaviour.

Of course the Party centre created the context for starvation by launching the Leap. After all, the famine affected the entire Sichuan basin: the mortality rate in 1959-61 exceeded that of 1956-57 in almost every county in central and eastern Sichuan. Only the Himalayan counties of western Sichuan escaped. This shows that there was a general macroeconomic policy failure, and local cadres cannot be blamed for that. Moreover, the famine was primarily man-made. Of course some districts were hard-hit by drought: over 50 per cent of the output decline in Fuling in 1959 was due to summer drought. But Fuling was the exception and even there the 1959 drought was devastating only because of the premature assault on the dongshuitian, the traditional system of irrigation. The Sichuan famine was not, therefore, primarily a natural disaster.

Yet in the genesis of this man-made catastrophe, the contribution of local cadres was far more important than the revisionists would have us believe. ${ }^{72}$ The worst excesses of central government policy during the Leap could be

71 A point emphasized in Chen, "Same sky," pp. 197-225.

72 The evidence for Sichuan during the famine thus supports Shue's (The Reach of the State, p. 131) view that "far from serving as robotic handmaidens of central domination, these stubborn, savy, and often cynical local officials came to constitute a formidable obstacle to real and effective central penetration and control on the ground." 
1008 The China Quarterly, 208, December 2011, pp. 990-1008

resisted, and the variation in death rates across the province shows that, in many parts of Sichuan, they were resisted by local leaders. These local cadres were not merely passive participants in the drama which unfolded across Sichuan in the late 1950s and early 1960s. Rather, in those parts of the province where starvation was extreme, local cadres were as much agents as victims. Attempts to shift the blame for the Great Famine from local leaders to the Party centre and to Mao himself therefore do not square with the evidence. The Party centre was in no sense as powerful as the revisionists claim: the starvation that occurred during the Leap depended as much upon the willing participation of a myriad of "ordinary" local cadres as it did upon the orders of Mao Zedong. 